\title{
The Influence of Brand trust, Social Media Marketing and e-WOM on interest purchasing in Snake Socks products in Surabaya
}

\author{
Moch Rifan Al Faizin ${ }^{1}$, Sengguruh Nilowardono SE.,M.SI ${ }^{2}$ \\ Narotama University Surabaya \\ rifanalfaizin3@gmail.com
}

\begin{abstract}
The purpose of this research are for known as brand trust, social media marketing, electronic word of mouth and purchase intention of Snake socks consuments product in Surabaya. .This research is a quantitave. The population and samples are based upon questionnaire that had been given to 100 respondents of Snake Socks consuments product in Surabaya. Data retrieval techniques by interview, observation and questionnaire. The method used is quantitative research method. For the method of data analysis using Path Analyze) with IBM SPSS 23.0 Data analysis that had been use are validity test, reability test, classic assumption test, and multiple linear analysis test. The result of his study showed that partially brand trust (X1), social media marekting (X2),electronic word of mouth (X3) has positive significant positive significant toward purchase intention (Y). While brand image gives impact toward two variables electronic word of mouth and purchase intention as the intervening variable.The research has a significant correlation towards employe performance $(\mathrm{Y})$ the value is $<0.05$.
\end{abstract}

Keyword: Brand Trust, Social Media Marketing, Electoric word of mouth, purchase intetion.

\section{INTRODUCTION}

Brand trust, social media is one of the factors to make a conversation that is spread by word of mouth or also called Word of Mouth in the real world. Word of mouth is something that many people talk about. Talks occur because there is a controversy that distinguishes things from ordinary and normal people see. eWOM as a "negative or positive statement made by actual, potential or previous consumers about the product or company where this information is available to people or institutions via the internet. Word of mouth and brand trust will later make people aware of a brand and seek information about the brand and eventually generate interest in consuming the product.

That buying interest is the stage of the respondents' tendency to act before the buying decision is actually implemented. Today many large companies have used social media as a way to market their products. Today's social media marketing has also penetrated MSMEs, they assume that using social media can suppress. The following is the people's buying interest seen from the sales statistics every year starting in the first year of the establishment of the snake socks business in 2016.

In 2016 the snake socks got a profit of Rp65.734.000 in 2017 earning a profit of Rp49.480.000 with a difference of Rp16.254.000 Snake socks experienced a decline in income in 2017 so I examined the prospect of this decline through the following variables. The phenomenon of the rapid growth of social media now raises a new trend in which many companies / MSMEs currently use internet technology as one way to market their products using social media, this is because companies / MSMEs do not need to spend a lot of money to provide information about their products. One example of SMEs that use social media in marketing their products is Snake socks that produce socks, using Instagram as a tool to promote their products. The difference between Snake socks and lanin socks is the motives of socks that were originally monotonous, changing to become more innovative and creative.

Based on the description above, the authors are interested in conducting research with the title "The Influence of Brand Trust, Social Media Marketing and eWOM on the Purchase Interest in Snake Socks Products in Surabaya". 


\section{THEORITICAL FRAMEWORK}

\section{Brand Trust}

(Kumar 2013: 69) that brand trust is described as the willingness of individuals to trust the brand's ability to satisfy their needs. In this situation where individuals cannot objectively evaluate the quality of the product in advance, brand trust plays an important role in reducing uncertainty in purchasing.

\section{Social Media Marketing}

According to social media (Kotler \& Keller 2012: 546), social media is a means for consumers to share text, images, audio, and video information with each other and with companies and vice versa. Social media allows marketers to shape public voices and presence on the web and strengthen other communication activities.

\section{Elektronic Word Of Mouth(E-WOM)}

In general, Word of Mouth is an oral person-to-person communication / oral communication between individuals to other individuals / between the sender and recipient of the message in which it has elements of the product, service or brand. Word of Mouth is talk that naturally occurs among people, Word of Mouth is the talk of genuine consumers. Word of mouth (WOM) is product information transmitted from persons to other elements of Solomon (2014).

\section{Interest Purchasing}

Interest purchasing occurs from various stages when advertisements enter consumers, ranging from a sense of attention to the ads displayed, then brings a sense of interest in the product advertised earlier, so consumers will start trying with what they know in the ad, from the stage they tried earlier will do a buying act (Tjiptono, 2013; 226).

\section{RESEARCH METHOD}

\section{Type of Research}

This research is quantitative method, he process starts from theory, then by using logic and derived research hypotheses accompanied by measurement and operational concepts, so that it can be concluded as research findings.

\section{Place and Time of Research}

This research conducted at Snake Socks Surabaya.

\section{Conceptual Framework}

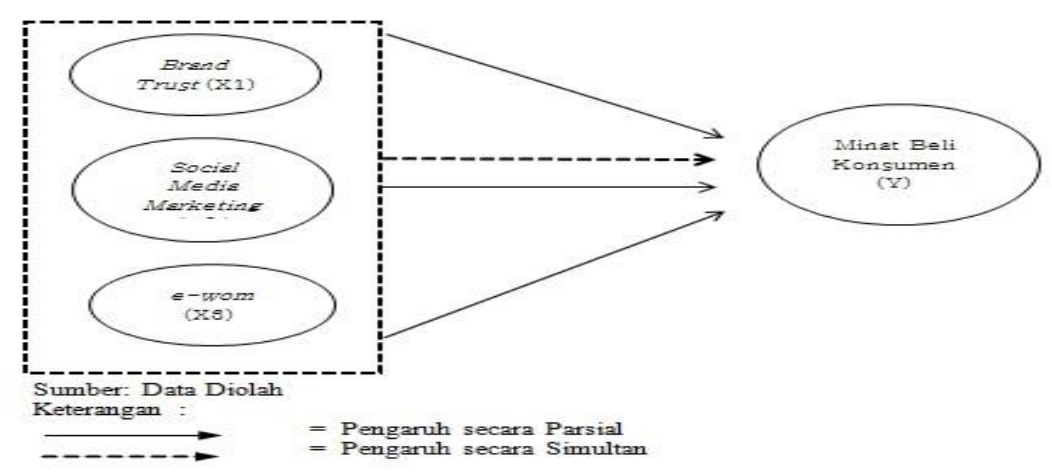

\section{Population and Sample}

According to Indriantoro and Supomo (2011: 45): "Population is a generalization area consisting of: objects / subjects that have certain qualities and characteristics set by researchers to be studied and then conclusions drawn. The population used in this study were all consumers in Snake Socks products in Surabaya. Because the population is not known, the determination of the number of samples to be used in 
this study will use the formula according to (Purba, Amir 2006) as stated below:

$$
\mathrm{n}=\frac{\mathrm{Z}^{2}}{4 \text { (Moe })^{2}}
$$

Where :

n: Number of samples

Z: Normal distribution level at a significant level of $5 \%=1.96$

Moe: Margin of error or maximum error can be correlated, here is set at $10 \%$ or 0.10 by using a margin of error of $10 \%$, then the minimum number of samples that can be taken is: $n=1.962 / 4(0.10) 2 n=96.04$ which is rounded to $96^{\prime}$

From the results of calculations, the sample obtained is equal to 96.04 to make it easier then rounded up to 100 respondents. So this study uses 100 respondents to be used as research samples.

\section{Data Collection Method}

Primary data is data originating from the original or first source [12] This data was obtained from the results of filling out a questionnaire regarding brand trust, social media marketing, eWOM and Purching interest a Snake socks products at Surabaya.

\section{Operational Definition of Research Variable}

According to (Suharsimi, 2006) research variables are research objects or what is the focus of research. In research the variable consists of 2 variables, namely the independent variable (X) which affects the factors chosen by the researcher and the dependent variable (Y).

$\mathrm{X} 1$ : Brand Trust. Brand trust is a dimension of viability, dimension of intentionality.

X2: Social Media Marketing. Social Media Marketing is a context, communication, collaboration, connection.

X3: eWOM. eWOM is a Platform Assistance, Venting negative feelings, Concern for other consumables, Extraversion / Positive Self, Social Benefits, Helping the Company, Seeking Advice

Y: Purchase interest. The interest in buying consists of attention, interest, desire, action, satisfication.

\section{Data Analysis}

Method Reliability and Validity Test

Ghozali (2005) a questionnaire is said to be valid if the question in the questionnaire is able to express something that will be measured by the questionnaire. An indicator is declared valid if $r$ has a significant level of less than 5\%. While according to reliability (Umar, 2000) is the accuracy, accuracy or accuracy shown by the measurement instrument. A question that has been asked valid in the validity test will be determined reliability by using the Cronbach alpha statistical test provided that the variable under study is declared reliable if the croanbach alpha value is above 0.6 .

\section{Multiple Regression Analysis Model}

The method of this analysis used in this study is multiple regression models approach the return. This method has been chosen to measure Brand Trust (X1), Social Media Marketing (X2), eWOM (X3) on purching interest $(\mathrm{Y})$. The basic formula of multiple regression analysis takes the following form:

$$
\mathrm{Y}=\mathrm{a}+\mathrm{b} 1 \mathrm{X} 1+\mathrm{b} 2 \mathrm{X} 2+\mathrm{b} 3 \mathrm{X} 3+\mathrm{e}
$$

Where :

Y: Purching interest

A: constants

b1, b2, b3: coefficient correlation

$\mathrm{X} 1$ : brand trust

$\mathrm{X}$ 2: social media marketing

X3: eWOM

E: error estimet 


\section{FINDING AND ANALYSIS}

\section{Reliability and Validity}

Based on the research shows that the value of alfa cronbanch is 0.965 which means that it is above acceptance limit of 0.6 therefore, the research instrument for relationship among the variable indicates good consistency and the data is acceptable. Based on research value of correlation index for relationship among variable independents (brand trust, socil media marketing, eWOM) with variable dependent (purchign interest) are greater than 0.3 and below the significant level of 5\% (0.05). The correlation between brand trust (0.835), Social Media Marketing (0.846), and eWOM (0.877) with purching interest (0.931) show a positive known. Therefore, the data is considered as valid

\section{Multiple Linear Regression Result}

Table 1. Multiple Linear Regression Result

\begin{tabular}{|c|c|c|c|c|c|c|}
\hline & & \multicolumn{2}{|c|}{ Unstandardizad Coefficients } & \multirow{2}{*}{$\begin{array}{l}\text { Standardize } \\
\text { d } \\
\text { Coefficient } \\
\text { s } \\
\text { Beta }\end{array}$} & \multirow{2}{*}{$\mathrm{t}$} & \multirow{2}{*}{ Sig. } \\
\hline \multicolumn{2}{|c|}{ Model } & B & Std. Error & & & \\
\hline \multirow[t]{4}{*}{1} & (Constant) & $-1,368$ & 1,097 & & $-1,246$ & 216 \\
\hline & Brand Trust &, 027 &, 038 &, 083 &, 724 &, 471 \\
\hline & eWOM & 221 &, 052 & 431 & 4,268 &, 000 \\
\hline & $\begin{array}{l}\text { Social Media } \\
\text { Marketing }\end{array}$ &, 174 &, 054 &, 321 & 3,232 &, 002 \\
\hline
\end{tabular}

Source: SPSS Output, 2019.

Based on the analysis result shows that the equation of multiple regression model in this research is shown as follows:

Where :

$$
\mathrm{Y}=-1.368+0.221 \mathrm{X} 2+0.174 \mathrm{X} 3+\mathrm{e}
$$

$\mathrm{Y}=$ Purching Interest

$\mathrm{X} 1=$ Brand Trust

$\mathrm{X} 2=$ Social Media Marketing

$\mathrm{X} 3=\mathrm{eWOM}$

$\mathrm{e}=$ Error

\section{Result of R Square}

Determination Test $\mathbf{R}$ and $\mathbf{R 2}$

The table above shows the Adjusted R Square value of 0.732 or $73.2 \%$. This shows that buying interest variables that can be influenced by brand trust variables, eWOM, social media marketing are $73.2 \%$. While the remaining 0.268 or $26.8 \%$ is influenced by other variables.

Table 2 detreminan result

\begin{tabular}{|l|c|r|r|r|r|}
\hline Model & $\mathrm{R}$ & R Square & $\begin{array}{l}\text { Adjusted } \\
\mathrm{R} \\
\text { Square }\end{array}$ & $\begin{array}{l}\text { Std. Error of } \\
\text { the } \\
\text { Estimate }\end{array}$ & Durbin-Watson \\
\hline 1 &, $862^{\mathrm{a}}$ &, 743 &, 732 & 1,879 & 1,970 \\
\hline
\end{tabular}


Test of Classical Assumption Multicollinearity Result

Table 3 Multicolinierity result

\begin{tabular}{|c|c|c|c|c|c|c|c|}
\hline & \multicolumn{2}{|c|}{$\begin{array}{l}\text { Unstandardized } \\
\text { Coefficients }\end{array}$} & $\begin{array}{l}\text { Standardized } \\
\text { Coefficients }\end{array}$ & \multirow[t]{2}{*}{$t$} & \multirow{2}{*}{ Sig } & \multicolumn{2}{|c|}{$\begin{array}{l}\text { Collinearity } \\
\text { Statistics }\end{array}$} \\
\hline Model & B & $\begin{array}{l}\text { Std. } \\
\text { Error }\end{array}$ & Beta & & & Tolerance & VIF \\
\hline 1 (Constant) & $-1,368$ & 1,097 & & $-1,246$ &, 216 & & \\
\hline Brand Trust &, 027 &, 038 &, 083 &, 724 &, 471 &, 208 & 4,803 \\
\hline $\begin{array}{l}\text { Social Media } \\
\text { Marketing }\end{array}$ &, 221 &, 052 & 431 & 4,268 &, 000 &, 265 & 3,780 \\
\hline eWOM &, 174 &, 054 & ,321 & 3,232 &, 002 &, 274 & 3,643 \\
\hline
\end{tabular}

Based on the table above, it is known that there is no independent variable that has a VIF value (variance inflation factor) greater than 10 and no independent variable has a Tolerance value of less than 0.10 so it can be concluded that there is no multicolonity between independent variables in the regression model

\section{Heteroscedasticity Result}

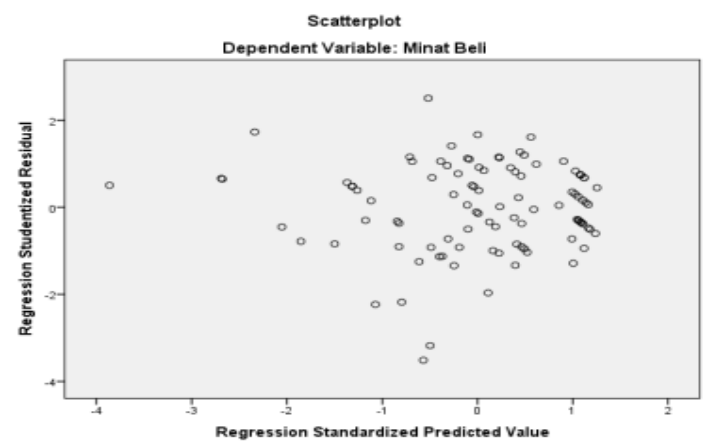

Figure 1 Heteroscedacity Result

The pattern of the dots is spreading and does not create a clear pattern. The dots are spreading above and below (zero) in the $\mathrm{Y}$ and it proves that the model is free from heteroscedasticity

\section{Normality}

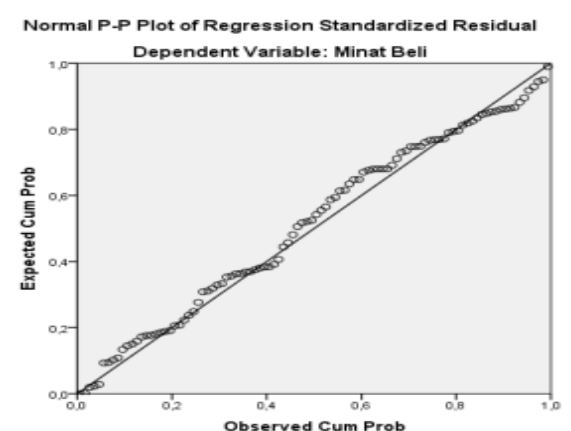

Figure 2 Normality Test Result

The data that spreads near the diagonal line and follow the direction of diagonal line. This proves that the model has passed the normality test. 


\section{Hypothesis Testing}

F Test

Tabel 4 f test result (simultant) ANOVA $^{\mathrm{a}}$

\begin{tabular}{|l|l|r|r|r|r|r|}
\hline \multicolumn{2}{|l|}{ Model } & \multicolumn{1}{|c|}{$\begin{array}{l}\text { Sum of } \\
\text { Squares }\end{array}$} & df & $\begin{array}{l}\text { Mean } \\
\text { Square }\end{array}$ & F & Sig. \\
\hline \multirow{2}{*}{1} & Regression & 970,922 & 4 & 242,731 & 68,769 &, $000 \mathrm{~b}$ \\
\cline { 2 - 7 } & Residual & 335,318 & 95 & 3,530 & & \\
\cline { 2 - 7 } & Total & 1306,240 & 99 & & & \\
\hline
\end{tabular}

Based on the above table it is known that the calculated $F$ value is 68.769 while the $F$ value of the temporary table $\mathrm{F}$ table is $\alpha=5 \%$ and $\mathrm{df}=(\mathrm{k}-1)=(4-1)=3$ and $\mathrm{df} 2=(\mathrm{nk})=(100-4)=96$ obtained F table of 2.70. Thus F count $>\mathrm{F}$ table $(68.769>2.70)$ it can be concluded that the independent variables simultaneously have an influence on the dependent variable. Then it can be seen from the probability value of the table that is equal to 0.00 which is smaller than the 0.05 level of significance. This means that brand trust, eWOM, and social media marketing variables together (simultaneous) have a significant influence on buying interest.

T Test

Tabel 5 t test result (Parsial)

\begin{tabular}{|c|c|c|c|c|c|}
\hline \multicolumn{6}{|c|}{ Coefficients $^{a}$} \\
\hline & \multicolumn{2}{|c|}{$\begin{array}{l}\text { Unstandardized } \\
\text { Coofficionts }\end{array}$} & $\begin{array}{l}\text { Standardizad } \\
\text { Coefficients }\end{array}$ & \multirow[b]{2}{*}{$\mathrm{t}$} & \multirow[b]{2}{*}{ Sig. } \\
\hline Madel & $\frac{\text { Coeffici }}{\mathrm{B}}$ & $\begin{array}{l}\text { Stdd. } \\
\text { Error }\end{array}$ & Beta & & \\
\hline \begin{tabular}{l|l}
1 & (Constant)
\end{tabular} & $-1,368$ & 1,097 & & $-1,246$ &, 216 \\
\hline \begin{tabular}{|l|} 
Brand trust \\
\end{tabular} &, 027 &, 038 &, 083 &, 724 & .471 \\
\hline ewom & 221 &, 052 & 431 & 4,268 &, 000 \\
\hline $\begin{array}{l}\text { Socail mesia } \\
\text { marketing }\end{array}$ &, 174 &, 054 & 321 & 3,232 &, 002 \\
\hline
\end{tabular}

\section{DISCUSSION}

Effect of Brand Trust on Buying Interests

Based on the results of the research that has been done, from the calculation of multiple linear regression shows that $\mathrm{t}$ count $<\mathrm{t}$-table $(0.724<1.66088)$ and the probability value sig. advertisement $>0.05(0.471>$ $0.05)$. So it can be concluded that brand trust (X1) has no significant effect on buying interest (Y) snake socks.

\section{Effect of Social Media on Buying Interests}

Based on the results of the research that has been done, from the multiple linear regression calculation shows that $t$ count $>\mathrm{t}$-table $(3.232>1.66088)$ and the probability value sig. advertising $<0.05(0.002$ $<0.05)$. So it can be concluded that social media marketing (X2) has a significant effect on buying interest (Y) of snake socks.

\section{Effect of eWOM on Buying Interests}

Based on the results of the research that has been done, from the calculation of multiple linear regression shows that $t$ count $>t$-table $(4.268>1.66088)$ and the probability value sig. advertisement $<0.05(0,000$ $<0.05)$. So that it can be concluded that eWOM (X3) has a significant effect on buying interest (Y) of the snake socks.

Brand Trust, eWOM, Social Media Marketing for the Simultaneous Buying Interest

Based on the results of research that has been done, from multiple linear regression calculations show that $F$ count $>F$ table $(68.769>2.70)$ and significance value $<0.05(0.000<0.05)$. So it can be concluded 
that brand trust, eWOM, Soial media marketing together (simultaneous) have a significant influence on buying interest.

\section{CONCLUSION AND RECOMMENDATION}

\section{Conclusion}

1. Brand Trust does not significantly affect Snake buying interest in Surabaya.

2. Electronic word of mouth (eWOM) significantly affects the interest in buying snake socks in Surabaya.

3. Social Media Marketing significantly influences the interest in buying snake socks in Surabaya.

4. Brand Trust, electronic word of mouth (eWOM), and Social Media Marketing simultaneously have a significant effect on the interest in buying snake socks in Surabaya.

\section{Recommendation}

Based on the conclusions that have been put forward, there are three recommendations that can be concluded from overall result as input that hopefully can be useful as suggestions, which are listed as flows:

1. For Companies. Companies must pay more attention to matters related to social media marketing products that are displayed, such as the content of advertising messages must be clearer, easier to understand and easier to remember so that the ads are more attractive and accepted so as to encourage consumer buying interest. The company must also pay attention again to brand trust to increase public trust in products that the company sells.

2. For Researchers. It is hoped that the next research will not be limited to the Brand Trust variable, electronic word of mouth (eWOM), Social Media Marketing, buying interest, but also add other variables in future studies.

\section{REFERENCES}

[1] Abdallah Q. Bataineh. (2015). The Impact of Perceived $e$-WOM on Purchase Intention: TheMediating Role of Corporate Image. International Journal of Marketing Studies; Vol. 7, No. 1; ISSN 1918-719X E-ISSN 1918-7203 Published by Canadian Center of Science and Education

[2] Hatane Samuel dan Lianto (2014). Analisis Ewom, Brand Image, Brand Trust, dan Minat Beli Produk Smartphone di Surabaya.Jurnal Manajemen Pemasaran,Vol. 8 No. 2 , Oktober 2014 Doi: 10.9744/Pemasaran.8.2.47-54 Issn 1907-235x

[3] Keller, Kevin Lane. (2003). Strategic Brand Manajemen. Second Edition. London: Prentice Hall.

[4] Kotler, Philip dan Armstrong, Gary. (2007). Dasar-Dasar Pemasaran (Principles of Marketing). Jakarta: Prenhallindo.

[5] Sugiyono. (2008). Metodologi Penelitian Bisnis. Bandung: Alfabeta [7] A. R. Septika Retno Palupi, "Pengaruh Tata Ruang Kantor, Kelengkapan Fasilitas dan Motivasi Kerja Terhadap Kinerja Karyawan,” Econ. Educ. Anal., 2014.

[6] Tjiptono, Fandy. (2005). Brand Management dan Strategi. Yogyakarta: Andi Offset.

[7] M. A. Fiqi, "Pengaruh Lingkungan Kerja dan Disiplin Kerja Terhadap Kinerja Karyawan," Ekomadania, vol. 1, pp. 215-252, 2018.

[8] Werdiningsih, Ratri (2012), Pengaruh Word of Mouth Terhadap Proses Keputusan Pembelian Produk House of Adity. Jurnal Institut Manajemen Telkom. 